\title{
Native Pacific Cultural Studies on the Edge
}

\author{
Vicente M Diaz and J K haulani Kauanui
}

$\mathrm{T}$

HIS SPECIAL ISSUE features work by Native and nonnative Pacific scholars that seeks to triangulate the arenas of "native studies," "Pacific studies," and "cultural studies." 1 We will return to what we mean by triangulation shortly. These invited works were presented at a two-day symposium, "Native Pacific Cultural Studies on the Edge," held on II-I 2 February 2000 at the University of California at Santa Cruz. The event was sponsored by the university's Center for Cultural Studies with funding support from a University of California Pacific Rim Research Grant. As joint organizers and conveners of the symposium, we each presented papers as well. One final participant, Donna Matahaere of Otago University, Dunedin, New Zealand, unfortunately could not attend. In addition to the papers presented here, the symposium included critical respondents and roundtable participants: Christopher Connery, April Henderson, Adria Lyn Imada, Glen Masato Mimura, Michael Perez, Joakim Peter, John Chock Rosa, and Dana Takagi (see a line-up of the program in the appendix). The event also featured an art installation by Angelina Naidu and Teresia Teaiwa- "Postcards from the Edge"-and an exhibit by Jewel Castro, "Daughters of Salamasina."

The symposium sought to explore notions of Pacific indigeneity as they circulate through geographical, cultural, political, and historical flows of people(s), things, knowledge, power-between islands and continents. We asked participants to discuss alternative grounds on which to stake native Pacific cultural studies for the twenty-first century. Our guiding question was What happens when the grounds of indigeneity (of Pacific Islanderness) get too fixed or move too far? What we wanted to feature most of all was what we wish to call native productions of indigeneity. We wanted to feature the edges of what is normally taken to be traditional native ter- 
ritory; in the face of diaspora and globalization, but without relinquishing the groundedness of indigenous identity, politics, theory, method, and aesthetics.

\section{On The Move}

The Pacific is on the move, unleashing forces along its edges (especially) that have the twin powers to destroy and to create. Long before modern theories of plate tectonics, or postmodern epistemologies, Pacific Islanders have enshrined this dialectic in cosmologies and performance, as well as in seafaring technologies and dynamic cartographies. At the dawn of a new millennium, Pacific Islanders continue a history of production and destruction through active participation in and resistance to a tide of forces that have swept our shores: colonialism, patriarchy, militarism, Christianity, nationhood, development, tourism, literacy, athletics, other forceful modes of modernity, and for us especially, scholarship. For descendants of ancient seafarers, and survivors of more recent and ongoing histories of colonialism and their displacements, these entanglements provide new opportunities for mobility and travel as well as new forms of incarceration and oppression.

In introducing the works that follow, we point to key areas of concern and questions that we believe crosscut the three fields and raise the cultural, political, and analytical antes in the contest over Pacific indigeneity. Our desire to address contestations over Pacific indigeneity by triangulating Native, Pacific, and cultural studies is drawn from kindred but distinct lines of critical questioning raised by a decade of academic conferences and publications across the Pacific and within a broader context of more vocal indigenous struggles. Peering at the horizon from multiple locations, we ask: What might cultural studies offer Native (Pacific) studies and vice versa? What are specific Pacific Islander contributions to cultural studies? How (or what) might cultural studies contribute to projects of decolonization and sovereignty struggles? And what could projects of decolonization offer cultural studies? In what follows, we provide a brief, thematic, and highly partial reading of signs that point us toward new terrain, uncertain seas, between the three areas. We begin with a highly customized method of triangulation as a native style of analysis and mode of politics.

In trigonometry the process of triangulation involves locating a point by using bearings from two other fixed points whose distance from each other is also fixed. Traditional Carolinian seafarers developed a native 
form of triangulation known as etak (moving islands; see Diaz 1996; forthcoming). This technique involves reckoning the distance traveled and one's location at sea by calculating the rate at which one's island of departure moves away from the traveling canoe and the rate at which a second reference island moves along another prescribed star course. The difference between triangulation in the trigonometric and traditional Carolinian seafaring senses is that the latter technique involves entities whose borders are in flux. For example, the highest point of an island can shift from treetops to mountaintops to particular cloud formations, continuing upward to a range of constellations, depending on one's distance from that island. More profound, perhaps, is the perception that the entities used for etak triangulation are themselves on the move.

In his already classic essay "Our Sea of Islands," Epeli Hau'ofa reminded us that contrary to modernist imaginaries of our world as a scatter of tiny, isolated, remote islands, Oceania is better understood as a sea of islands whose watery domain is a pathway that connects rather than isolates us (1993). The belittling economically and geographically deterministic view of Oceania overlooks historical processes and forms of "world enlargement" carried out by island peoples that make nonsense of national and economic boundaries and zones that mark colonial legacies and postcolonial relationships (see also Kabutaulaka I993). Hau'ofa conceived of this "world enlargement" as a vision whereby Pacific peoples see more than just the ever-growing surface of the land as home; they also look to the surrounding ocean, its underworld, and the heavens above.

The islands themselves are also on the move, and if there is a stable point from which one gauges one's position, it is the canoe. As David Lewis once remarked, in traditional seafaring one got the sense that the canoe was stationary while islands came and went (1970). As a technique for successful travel, whose most urgent stakes are the peoples' survival and stewardship of place, triangulating among moving islands in a fluidic pathway involves a clear and unambiguous sense of one's place at all times. The islands may move, but one must always know their location at any given time, as indexed by their signs in the natural and supernatural worlds. To lose one's place, to not know where one's island is, or to no longer be possessed by that island, is to be perilously lost at sea. While this mobile model privileges oceanic voyaging and even "world traveling," we suggest that it might serve as a tactical figure for indigenous political and cultural struggles. Here we include the more "land-based" Islanders across the Pacific who may not, as Margaret Jolly has reminded us (this issue), 
necessarily reckon their senses of identity and place via canoe and seafaring traditions (but see Hau'ofa's sustained pitch, I997, 2000). As we suggest later, there is something landed and very materially grounded in seafaring metaphors and sensibilities. We also acknowledge the mobility in land-based subjectivities, whose complex conjunctions in the Pacific have given us (and White and Tengan, and Clifford) the opportunity to intervene in what seems to have quickly become a polarized debate over "roots" and "routes" in Native and cultural studies.

\section{Natives Study/Native Studies}

First, we begin by acknowledging the persistence of deep native "roots" throughout up to three centuries of European and American imperialism and colonialism. We do so through an intellectual and academic milieu that has pronounced the death of the subject, the pitfalls of essentialism, and the predetermined inscription of identities. Central to native studies are the struggles for sovereignty and decolonization for Islanders resisting benevolent and malevolent assimilation into larger, more powerful, entities. These are best expressed in $\mathrm{M}$ ori studies in Aotearoa and Te Wai Pounamu New Zealand, at the Center for Hawaiian Studies at the University of Hawai'i at M noa, in Aboriginal Studies in Australia, Chamorro Studies in Guam, and Pacific literary movements out of the University of the South Pacific and the University of Papua New Guinea. Standing firmly at the center of these political struggles is the Native who is selfand collectively identified through genealogy as well as through imposed categories such as race and blood, and through native perspectives, sources, values, and lifeways. Central to the research and teaching agenda are acts of political, cultural, and historical reclamation and stewardship, including "competence" curriculum in language, cultural, and spiritual practices. But also increasingly central to the political and cultural movements is the need for more native-based research, theory, and methodology (Smith 2000). Scholarship for us involves at least two interconnected fronts: the identification and dismantling of colonial structures and discourses variously conceptualized and theorized, and cultural reclamation and stewardship.

Second, and paramount to the continued existence and viability of Pacific Islanders, is an equally deep-rooted sense of place. The land and sea constitute our genealogies and, not surprisingly, they lie at the heart of the varied movements to restore native sovereignty and self-determinations. 
Land and sea are ways by which peoplehood is fashioned. Using two examples from the region misnamed "Micronesia," we find that Chamorros of the Mariana Islands refer to themselves as Taotao Tano (people of the land) amid the majority of nonindigenous residents of that archipelago, while atoll dwellers from the central Carolines prefer to distinguish themselves from their relatives in the high islands as Re Metau (people of the sea). Interestingly, "high islanders," such as those who reside on the bigger islands in the Chuuk Lagoon, sometimes invert the originary category by referring to the Re Metau as "Islanders." In addition to these regional names, there are highly localized and politicized distinctions within each. For example, some Chamorros of Guam distinguish between the Taotao Tatte (people of the south) and those from elsewhere on the island, or between those who have remained, and the po-asu, who have grown up elsewhere. ${ }^{2}$ Among the Re Metau there is a distinction between those who have "remained" (in the seafaring atolls!) and the Refalawasch, who have settled the islands of the Northern Marianas since the eighteenth and nineteenth centuries. In the Northern Marianas, the Refalawasch further distinguish themselves in fundamental terms of different voyaging histories and geneaological ties to the central Carolines. In the Northern Marianas, as elsewhere across the Pacific, the strong links between identity and land become especially charged in colonial contexts. For example, some Refalawasch claim taotao tano status on the basis of having settled these islands before the Chamorros began to return after their forced removal to the southern island of Guam by Spanish conquistadors in the seventeenth century. Such fine and often highly contested particularities of Islander identification with the land can be found across the Pacific. ${ }^{3}$

Roots and their identities and traditions are also routed, both metaphorically and literally, as in the sense of moving islands indicated earlier. ${ }^{4}$ This routedness is also present in native discourses on the inseparability of land and blood. In the act of reclaiming her ancestral Banaba (also known as Ocean Island), Teresia Teaiwa mapped its literal displacement through the history of phosphate mining and the circuits it travels in the form of fertilizer destined for the farming, dairy, and alcohol industries in New Zealand and Australia (1997). Elsewhere, Teaiwa made these and other links explicit: "Borrowing a notion from Black British scholar Paul Gilroy, I have come to understand . . . that to search for roots is to discover routes" (I995). Elsewhere, too, she brought them all together, thus: "We sweat and cry salt water, so we know that the ocean is really in our blood" (in Hau'ofa 1997, I24). 
In another example that points to the kinship ties between people and land-and their mobilities-we know that Hawaiians refer to land as 'aina - that which feeds. This also happens to be the word that Samoans use to gloss family-'aiga. Hawaiians commonly refer to family as 'ohana. An etymology of the word 'ohana itself is useful here. 'Oha is the taro corm (the $n a$ after 'oha pluralizes) grown from the older roots, especially from the stalk, and is figurative for offspring and offshoots. Elsewhere, Kauanui has theorized this concept as it might also describe "off-islanders" in order to describe Hawaiian diasporic subjectivity-in relation to Hawaiian sovereignty struggles - as compatible with Hawaiian notions of 'ohana (I998). As Hawaiians living outside Hawai'i are often referred to as "transplants," one might argue that this label assumes the familial and genealogical connection between those living on and off the islands. Transplanting implies a binary, operating as a relational construct. But transplanting also marks the possibilities in taking root and growing in a different soil while continuing to maintain an originary location and emphasizing indigeneity as a central form of identification. 'Oha can be (trans)planted and become new "parent" shoots, which is one way distinct new varieties of taro have come about. While taro is commonly reproduced by transplanting the treated huli (a cutting from the stalk) to grow new plants, the 'oha, smaller offshoots from the larger corm can also be planted. In those 'oha plantings most new varieties are created. Thus buli transplants might be the best metaphor for Hawaiians who migrate to new shores, whereas 'oha better describes those born outside Hawai'i because the 'oha grows underground (and in this case, in new soil) unlike the stalk of the huli. In relation to Hawaiian nationalism, the concept of 'ohana might be evoked literally and figuratively in on-island nationalist discourse and in questions of concern in attempts to include off-island Hawaiians. Within 'ohana and "transplant," the genealogical connections between people and land are primary, and even work geographical distance.

Third is the centrality of native language and indigenous discourse as markers of deep difference. Oceania is home to the world's largest concentration of vernaculars that are simultaneously in danger of becoming lost and undergoing robust revitalization through practices such as the $k$ hanga reo and $p$ nana leo (language nests) among the $\mathrm{M}$ ori and Hawaiians, respectively. As we have indicated, native language and discourse are more often than not "rooted" in land, especially in particular landscapes and seascapes across the Pacific. Like them, "rooted" language and discourse are tenacious and durable, on the move-with movement 
defined variously: as voluntary, in exile, and even forcible (Trask I993). In the face of Native and nonnative linguistic imperialism, of demise and survival, we mark other key concerns for a native Pacific cultural studies: Does language make the Native Native? Can the Native still be Native without fluency in the language? Where do creoles and pidgins, and the assortment of native brands of English figure in the constitution of indigeneity? And how does the "loss" of language also mark a people's experience as a profoundly Native one?

Fourth, there is the arena of spirituality and faith in multiple forms: "traditional beliefs" (which have long been denigrated by outsiders, including academics, as "animist," "superstitious," "legends," and "myths") and their manifestation in and transformation to Christianity. Across the "modern" Pacific, traditional spirituality and practices persist through belief in malevolent and benevolent beings inhabiting people, places, and other beings that pass through the very circuits that the people, places, and beings also travel. Such practices can also persist through Christianity. As many observers of Christianity in the Pacific have noted (see also Clifford 468-490), traditional spirituality does not simply cease on conversion as if conversion were a one-way act. ${ }^{5}$ Indigenous conversion to Christianity ranges from syncretic to inseparably hybrid and constitutes complex and contested sites of native agency.

We want to emphasize in our ongoing discussion of native studies in the Pacific, the interrelational and contextual character of roots and routes. These are not intrinsically oppositional; if our roots are strong, deep, grounded, it may be precisely for their dynamic abilities to keep pace with the variable forces of change. And then again, many have not.

\section{Natives Study/Pacific Studies}

The field of Pacific studies has demonstrated mobility as shown by its imperialist and orientalist beginnings, which mined Oceania's natural and cultural and intellectual resources, and engendered the Pacific as an insular tabula rasa for Euro (and particularly) American national desires and anxieties. That trajectory also includes its post-World War Two accommodation of native political and cultural agencies, to its recognition of postindependence and post- and neocolonial conditions and global forces. ${ }^{6}$ Shifting, and complicit with global forces and western hegemony, Pacific studies labors to keep pace with local, regional, national, and international interests through academic cooperation and collaboration, with 
the fields of anthropology, history, geography, and political science at the forefront. ${ }^{7}$ By the latter part of the twentieth century, the field of Pacific studies proper would be dominated by the University of Hawai'i's Center for Pacific Islands Studies, along with its annual Pacific Islands Conference and its premiere journal The Contemporary Pacific, the Research School of Pacific and Asian Studies at the Australian National University, the MacMillan Brown Centre for Pacific Studies at Canterbury University, Christchurch, and the Centre for Pacific Studies at Auckland University. ${ }^{8}$ Other flagship entities include the Institute of Pacific Studies at the University of the South Pacific, the journal Pacific Studies (published by Brigham Young University at L 'ie) and the ever-growing University of Guam's Micronesian Studies Program (including its shortlived journal Isla: A Journal of Micronesian Studies). Moreover, there are now Pacific studies programs at Oregon State University, Victoria University of Wellington in New Zealand, Kagoshima University in Japan, and the University of Nijmegen in the Netherlands.

Pacific studies features the work of individual scholars usually affiliated with international professional associations such as the Pacific History Association (PHA), ${ }^{9}$ created in the early I960s, concurrent with the beginnings of decolonization in the Pacific. Its creation heralded a turn from imperialist to island- and Islander-centered historiography. Nearby, anthropologists continued to do their work (see White and Tengan, $38 \mathrm{I}-4 \mathrm{I} 6$ ), and the creation of the Association for Social Anthropology in Oceania in the late I970s would greatly facilitate the proliferation of fieldwork as well as reports and publications. ${ }^{10}$ By the late I970s and I980s, historians and anthropologists had begun to collaborate to develop a still influential, still compelling, Pacific version of ethnohistory or historical ethnography-in Australia, New Zealand, and Hawai'i-to better keep pace with native agency in historical motion. (Or is it historical agency in cultural motion?) By the mid-I990s we saw new developments, such as the European Society for Oceanists, which now holds biennial conferences and has cooperative agreements with the Universities of Heidelberg, Aarhus, and Nijmegen. ${ }^{11}$

Pacific studies can be likened to a canoe through which extensive and systematic interdisciplinary and academic focus on the Pacific has taken place-one that finds a new generation of Pacific Islander scholars. In the last decade, a number of major academic conferences that spanned the Pacific focused attention on indigeneity, power, and knowledge. These, in particular, make up some of the lineages we trace in the genealogy of Native Pacific Cultural Studies that would soon be, more fundamentally, 
on the "edge." These gatherings included: Island Discourses (PHA Guam, I990), From the Inside Out (CPIS, Honolulu, I994); Work in Flux in Pacific History 12 (Melbourne University History Department, I995); Contested Ground (CPIS, Honolulu, I995); History, Culture and Power in the Pacific, (PHA and CPIs, Hilo, I996); Featuring Paradise (CPIs, Honolulu, I997); Out of Oceania (CPIS, Honolulu, I999). ${ }^{13}$

In this milieu, issues of identity, culture, tradition, kastom become seen as political and politicized, as critical scholarship begins to consider the politics of local cultural production within the contexts of nationalism, globalization, and diaspora. In the main, however, these applicationsmost notably the now infamous "invention of tradition" debate (or debacle?) - in the Pacific setting have not been engaged by native scholars and intellectuals beyond charges that they represent newer forms of academic imperialism and renewed efforts at reinstating white academic authority (Trask 1993; Tobin 1995; Hau'ofa 2000; see also White and Tengan $38 \mathrm{I}-4 \mathrm{I} 6) .{ }^{14}$ The fact that critical calls to acknowledge the politics of culture and identity, and the "invention" of tradition have come largely from haole or pakeha scholars located at institutions in the most heavily colonized islands in the Pacific-Aotearoa and Te Wai Pounamu New Zealand, Hawai'i, and Australia-only adds to the heated polarizations. Still, for its presence, its resources, its ability to facilitate increasing numbers of Pacific Islanders in the academy, its ability to be used, Pacific studies' mobility continues to serve as a particularly seductive vessel for us. This same mobile effect also impels us toward cultural studies.

\section{Natives Study/Cultural Studies}

Though there are many strands of "cultural studies" since the early work produced at the Birmingham School, much resonates with the "predicament" of restless islands and Islanders. ${ }^{15}$ This is especially the case for those of us interested in scholarship as a form of knowledge, power, and identity in general, and from variously defined diasporic histories. We draw from nuanced critiques of power from the political and historical experiences of failed (or ongoing) revolutions in the first world (various critiques of race, ethnicity, class, gender, sexuality, and science). Alongside the unfinished nationalist liberation movements in the third world (the postcolonial and subaltern sources of criticism) that include various sites in the Pacific (which call for a hyperpoliticizing of our ideas and practices, especially those of academic interdisciplinarity) there is the still colonized "fourth world," which also includes Oceania. To the extent that 
academic practices have proven to be a major bastion of colonialism and imperialism in the Pacific, cultural studies can (but does not automatically) serve as a constant reminder of the varied forms of co-optation within systems of oppression. While we reclaim coveted "agency" in our histories, we are keenly aware that we need not lose the specificities of our cultural and political histories in order to appreciate how hegemony and colonial discourse operate through complicity and consent, especially through the production of native identities and cultures.

A second, related point that cultural studies helps us contend with is the constructed as well as the contested nature of our cultures and our identities. Though we know the latter intuitively (not least from raw experience), cultural studies nevertheless reminds us that culture and identity are neither innocent nor pure. And neither is scholarship on culture and identity. While hybridity may better describe the condition of things, and can be harnessed for our own strength, we aim to take care that its value as an analytical tool is not used to commodify or cheapen our own sources of empowerment. Cultural studies and its allied critiques manifest a particularly compelling understanding of how power operates through the coproduction of native identities and culture and how resistance can come from a refusal to submit to reified identities. While such theorization appears to banish native subjectivities (variously self-referenced as Kanaky, K naka Maoli, ' iwi Maoli, Tangata Whenua, Taotao Tano, Re Metau, and so on), we suggest the need to historicize these categories in terms that do not sacrifice their manama, mana, or life force. Cultural studies has been remarkably distant, if not hostile, to indigeneity. Yet in this, a deep suspicion toward the stereotypic Native is one characteristic that is ultimately appealing. As we have labored to show, the injection of mobility in how we conceptualize identity and culture can be liberating so long as the native is not lost altogether. In this volume, for example, Clifford stresses modes of native mobility and commuting, while Gegeo emphasizes modes of primordial dwelling, even within diaspora.

A third node in cultural studies is the political and analytical promise and pitfall of such dwelling in the diaspora. ${ }^{16}$ One finds more Pacific Islanders in places like Auckland, Sydney, Seattle, Los Angeles, and San Diego than at "home." 17 And "off-island," these Islanders refuse to abandon their island identities. Moreover, many return to the islands for extended periods. For us, the condition of diaspora at the end of the twentieth century and the beginning of the twenty-first is closely linked to neocolonialism and postcolonialism, including the globalization of local ideas, things, and people. This condition becomes attenuated when we 
recall earlier widespread movements via canoes out of Southeast Asia, or consider the "internal" diasporas that obtain within the boundaries of the nation-state and the regions.

Culture, identity, and politics become even more complex when travel and migration are not restricted to movement beyond one's "national" boundary, especially when the contours of one's nation are themselves in flux. Using the Hawaiian case as just one historical example, there is a need to account for Hawaiian movements in their respective contexts, especially in light of deracinating discourses that continue to perpetuate the notion that all Hawaiians are in or directly from Hawai'i, or that anyone who migrates from Hawai'i must, therefore, be "Hawaiian." These assumptions continue to mask the historical trajectories of Hawaiian presence on the US mainland, which dates back to I 788 on the west coast. There are different genealogies of Hawaiian migration, many of which predate the colonial migrations that followed the US annexation of Hawai'i in I 898. After that time, Hawaiians' out-migration was from US territory to US state and eventually from state to state (such as from Hawai'i to Texas) and state to territory (such as from Hawai'i to Guam).

Unfortunately the more common view, in popular and mainstream academic discourses (both native and nonnative alike), is to regard displaced Islanders as having forfeited their heritage. As the argument goes, their distance from the islands is perceived, rather than their journeys back and forth, which might be viewed as essential to the making of island traditions (or nationalist formations). At the same time, their critical distance from home has the effect of reinforcing the insular and insulating ideas of the home islands as exclusive sources of authenticity.

Again, we ask how can indigeneity be better understood in terms of native travel and movement? What might a grounded, rooted cultural studies offer native studies? One common theme that runs throughout the papers and addresses that follow is that of the mutually productive relationship between roots and routes.

\section{THE Work}

Teresia Teaiwa's "Lo(o)sing the Edge," is a split piece with two different narratives tracing the issues that a "Native Pacific Cultural Studies" raises and provokes while tracing its formation from a number of the Pacific studies, history, and anthropology conferences mentioned. Teaiwa explores conceptual components and provides a partial history of intellectual and professional trajectories "of the big and little currents that have 
shaped the gatherings of Native and Pacific scholars that preceded the UCSC symposium." Assessing the last ten years in this emergent work, she opens things up considerably, identifying the in-between spaces of the fields and the sometimes very different locations where we as scholars find ourselves. She argues that there are particular essentials for the Edge: "The native is personal. The personal is essential. For the Edge .... The native is hybrid. Hybridity is essential. For the Edge." Alongside these scholarly forms, where she notes that cultural studies has a theoretical edge, Teaiwa problematizes the location of the Native "at the Edge of cultural studies." She notes that the relationship between Native and Pacific studies has not yet been addressed and raises a series of questions in an attempt to define their different constitutions.

Teaiwa explores edges from the vantage points of two "cross" roads of sorts-Santa Cruz and Fiji (whose names in the Spanish and Polynesian languages refer to crossings) - for her own (and certain others') personal intellectual production in a burgeoning Native Pacific cultural studies. As a "Holy Cross" at the edge of the Pacific rim, Santa Cruz offers a leading edge in cultural studies and "high" theorizing. But she also draws attention to its limitations by contrasting it (and cultural studies) from the perspectives of a Pacific studies located and immersed in living and working in islands such as Fiji: "Pacific studies is not only an academic field; it is an especially intimate field that people enter, often with highly personalized stakes." Teaiwa warns that "as long as Pacific studies continues to achieve its critical edge from the edges of the Pacific, its contributors to knowledge production will remain largely impotent, irrelevant, and unwelcome in the face-to-face realities of the islands." Moreover, Teaiwa keenly reminds us that the ocean, ultimately, has the edge.

Jonathan Kamakawiwo'ole Osorio's paper opens with the title question "What Kine Hawaiian Are You?" instantaneously bringing to the surface an acknowledged variation among Hawaiians. He traces the imposition of racial identities and the role of the law in American colonization in Hawai' $i$, as well as indigenous racial consciousness. He does so by offering an I 887 mo'olelo - a fragment of Hawaiian history-about a small group of conspirators representing a minority of Caucasian residents and citizens of the Hawaiian Kingdom who forced King David Kal kaua to sign a new constitution of their own design. In the political rallies that followed, Natives who supported the new constitution (and who exhorted Hawaiians to rally around it) were ridiculed by opponents who were still often divided over whether to boycott the coming elections or to try and 
take over the government through the vote and amend the constitution. Osorio ties this tale to the contemporary context of US reconciliation hearings in Hawai'i.

As Osorio shows, the mo'olelo resonates strongly with the predicaments facing Hawaiians today, all too underscored by the recent US Supreme Court ruling in Rice versus Cayetano. In that case, the court decided that state-sponsored elections for Office of Hawaiian Affairs trustee positions, which were open to Hawaiians only, violate the Fifteenth Amendment to the US Constitution. As Osorio suggests, this ruling has renewed debates over who counts as Hawaiian and the fraught condition and burden of indigenous political participation and representation. For Hawaiians, he argues, "Our conceptions of race, nationality, and class are drawn by our own past, especially our colonial relationships with Americans." Examining racial identification among Hawaiians in response to colonial processes and experiences, Osorio reminds us, "Native peoples have consistently argued that ancestry and blood matter in the complex adoptions of culture and identity." For Hawaiians, this often means that one's Hawaiianness still holds considerable salience and is accorded importance in relation to kin and identity in spite of-or perhaps because of-common "racial intermixture," counter to common presumptions about and misrepresentations of Hawaiians.

Explicitly naming the political stakes in Hawaiian racial identification, he argues that the question of "who we think we are" is the very foundation of Native cultural studies. Certainly this question is quite central to Hawaiian studies. Exploring political positioning and political investments, Osorio unabashedly opens up a space to look at contemporary fragmentation and conflict among Hawaiians in relation to notions and practices of $l$ hui-alternately defined as peoplehood and nation-in the face of American usurpation. This nineteenth-century mo 'olelo is an early critical example of political dispute among Hawaiians facing American incursion. It demonstrates the subsequent difficulty of native unification for the purpose of opposition-even in withholding consent or refusing incorporation within the foreign (white male American) body politic organized by racially exclusive constitutional developments. Through the use of mo 'olelo, Osorio's work offers one methodological form within Native Pacific Cultural Studies. The edge in his work is one that defies easy readings of indigenous nationalism, where Hawaiian kinship practices and processes of identification continue to endure considerable assault through the racializing technologies of the state. This edge persists amid the tension 
between participating in state and US electoral politics and nurturing a defiant Hawaiian national(ist) spirit.

In "Disappearing Worlds: Anthropology and cultural studies in Hawai'i and the Pacific," Geoffrey White and Ty K wika Tengan discuss practices of anthropology in the Pacific, mapping their own triangulation in relation to the emergence of cultural studies and Native (Pacific) studies. They draw out the relations between the reinvention of anthropology's disciplinary identity and the reimagining of the Pacific region as a geocultural space that emerges "in the border wars with native scholars on the one hand and with interdisciplinary cultural studies on the other." White and Tengan trace various shifts and debates within the field of (cultural) anthropology to account for the exclusions of and contributions by Pacific Islanders, pointing out that much of the twentieth-century foundational work in the field was conducted throughout the Pacific. They draw attention to the absence of Pacific Islanders and, specifically, of Hawaiians as authors, agents, and practitioners of anthropology. To that end, they probe institutional practices and focus on the history of Hawaiian anthropology at the University of Hawai'i. As a case study, that site allows them to look at ways that disciplinary models and practices have worked historically to authorize and reinforce dichotomies that separate-both structurally and epistemologically—native subjects (always already constructed as informants), from anthropological agents (always already assumed to be nonnative and outsiders). Alongside this case study, they assess Clifford Geertz's review essay (I998) of James Clifford's book Routes: Travel and Translation in the Late Twentieth Century (1997) to examine notions of "cultural boundary crossing," and the ways in which fieldwork as both ideology and practice enforces separation between anthropology and native studies.

White and Tengan call attention to the emergence of a significant number of native authors and activists concerned with issues of culture, history, and politics. They focus on a new wave of formative cultural production among Pacific Islanders-such as literary fiction, film, and video-as creative forms of interruption, intervention, and influence. These forms have served as alternate knowledge production and are also a force with which the discipline of anthropology must reckon as anthropology reconceptualizes the objects of its research, devises new approaches to fieldwork, and otherwise engages in dialogue with a range of interlocutors. Moreover, White and Tengan argue that the shifting politics and practices of cultural representation in the Pacific are not only transforming anthro- 
pology, but are enabling various kinds of possibilities with both native and cultural studies.

Margaret Jolly's "On the Edge? Deserts, Oceans, Islands," situates itself in terrain still being shifted by the interplay of deep ecological and later colonial and postcolonial time and event, native and nonnative agency, and personal and academic struggle. She begins with some personal "millennial tales" set at Lake Mungo, in the center of Australia, far out of range of the present Pacific Ocean, to "reflect on how our imagined geographies of edges and centers, of peripheries and interiors are mirages of the geopolitics of our present." With critical self-reflexivity, she proceeds to explore representations and self-representations of Pacific indigeneity in the context of settler colonialism, focusing first on the revival of seafaring across the Pacific, and then on four major Pacific art and cultural exhibits at Port Vila, Noumea, Wellington, and Sydney.

For example, noting some Melanesian protests over the privileging of seafaring rhetoric emanating from Polynesian and Micronesian delegates to a recent convention ("There is a big difference between living in the interior of a large mountainous island and living in archipelagoes of smaller islands or on coral atolls"), Jolly challenges Hau'ofa's and more recent evocations of seafaring metaphor and sensibility to speak on behalf of the entire Pacific. She observes that such intraregional interventions (against already compelling interventions by Hau'ofa and others) are "not just an articulation of differences in geographical position, nor an indigenous insistence on being Melanesian as against Polynesian or Micronesian. Such conversations also reflected differences between Islanders in how they were situated in the global geopolitics of state forms and migration patterns." She questions just how applicable the seafaring "world traveler" vision is in the face of this difference, "especially for those people of the southwest Pacific who, because of border patrols by nation states, the exclusionary policies of migration, and sheer poverty, are not able, even if they so desired, to move from their newly independent states." Jolly reminds us that they often migrate in more localized movements within the world of the archipelago or nation-state and insists on the importance of discussing differences between Islanders without creating new essentialist types based on any dichotomy of "roots and routes." Moreover, she maintains that Pacific peoples live in "both spatialities and deploy metaphors of both groundedness and mobility, settlement, and detachment.”

Jolly then directs the theoretical and historical nuance to contemporary 
Pacific visual arts to suggest how relations between indigenous peoples, settlers, and migrants are differently imaged in the four cities mentioned. She finds that at the relatively new Vanuatu Cultural Centre, older repatriated materials were exhibited alongside contemporary work, and probes their alternate meanings within the context of Vanuatu as a recent postcolonial nation-state. At the Tjibaou Cultural Centre in Noumea, New Caledonia-a building "unsurpassed in the Pacific for its architectural splendor and its expensive high tech virtuosity"- she finds contemporary works that stress regional affiliations-work by Kanak and other Pacific, Aboriginal, and Torres Strait artists. Here Jolly considers the significance of such inclusive exhibits, given the Kanak movement for independence against the possibility of French efforts to paint over lingering criticism of its colonial nuclear legacy in the Pacific. In Wellington, Aotearoa New Zealand, she dwells on the new Te Papa National Museum. Here, Jolly describes the $\mathrm{M}$ ori Halls that include both traditional and contemporary sculptures and carvings, alongside paintings and even a marae, in which she scrutinizes the displaying practices, including unsuccessful attempts to portray a bicultural society of Pakeha and $\mathrm{M}$ ori people, and the limited number of exhibits by Pacific Islanders. Finally (and back to) Australia, but now at the Pacific Wave festival in Sydney, Jolly focuses on two simultaneous exhibits in the Casula Powerhouse-Weave and Furious. Reflecting efforts "to bring contemporary art exhibitions to white working class and immigrant communities," the shows feature weavings and plaitings by Pacific and Aboriginal women in the former, and rather incendiary paintings lashing out against white racism in Australia and authority and Christian hypocrisy in S moa in the latter, including organizers' efforts to soften the fury. Her discussion of contemporary visual arts and architectures offers rich sites to explore different understandings, articulations, and representations of indigeneity and diaspora.

The first of two keynote addresses (in the Dialogue section), James Clifford's "Indigenous Articulations," resuscitates the image and words of the late Kanak independence leader Jean-Marie Tjibaou and British cultural studies founder Stuart Hall's "politics and theory of articulation” to theorize the historical depth and the cultural reach (or is it cultural depth and historical reach?) of Pacific indigeneity. Framed by a recollection of his meetings with Tjibaou while doing fieldwork for his dissertation set in New Caledonia, and recent readings of Tjibaou's (posthumously published) writings, Clifford observes both the deep significance and the wide reach of an indigenous sense of place and politics made pos- 
sible by what he is tempted to call "indigenous commuting." And for Clifford, Stuart Hall's theory of "articulation," an updating of Gramsci's critique of hegemony from the conditions of British working class and Black diasporic insurgency, offers a possible theoretical and political mode of keeping pace.

Articulation, according to Clifford, suggests discourse or speech, but speech that is a composite "from a vastly greater repertoire of semiotic possibilities .... So an articulated tradition is a kind of collective 'voice' but always in this constructed, contingent sense." Articulation also refers to concrete connections, such as joints, and as such, according to Clifford, "Something that's articulated or hooked together . . . can also be unhooked and recombined." For Clifford, articulation, "offers a nonreductive way to think about cultural transformation and the apparent comings and goings of 'traditional' forms" that at the turn of the twentieth century are expressed in troubling ways (via Christianity, sovereignty, nationalism, independence). It is a useful way to keep pace with "indigenous commuting" in terms of both the dynamics of native movement in time and space, and, through older meanings of the word "commute," the dynamics of exchange and interaction with the other.

Thus, but within important limits, according to Clifford, "articulation" permits us to acknowledge and appreciate longer, deeper histories of indigenous articulations such as "landedness," a "grounding" which "offers a sense of depth and continuity running through all the ruptures and attachments" of neo- and postcolonialism, of diaspora and exile. Indeed, for Clifford, "articulation" offers a better alternative to the "invention of tradition" stances in the theoretical flagging of the political, contingent, contested dimensions of native tradition in the postwar Pacific, which has questioned native authenticity and erupted into struggles over anthropological versus native authority. According to Clifford, these have "tended to obscure the historical challenge of representing sequential and overlapping processes of cultural continuity, rupture, transformation, and revival.”

We point out that Clifford's assessment of Hall's applicability to the Pacific is itself "articulated" by his own considerations of several "broad" historical forces: the historical and cultural specificities of "belated" decolonization in the Pacific; postwar native engagement with "global" forces of capital; native diaspora; the limits and the possibilities of traveling theory, especially of cultural studies; and finally, the historical and cultural depth-including the centrality and portability of land and place, 
within which these interactions take place. Indeed, Clifford argues for "a more nuanced vocabulary, [to] find complex ways to represent dispersed and connected populations."

The second keynote, David Welchman Gegeo's, "Cultural Rupture and Indigeneity: The Challenge of (Re)Envisioning 'Place' in the Pacific," tackles a precoup Solomon Islands terrain. He articulates the dynamic features of indigeneity, some of which may fly in the face of postcolonial theories of diaspora. In linking the enduring forms of cultural rupture to colonialism and political ruptures to postcolonial nationalism, he argues for the necessity of documenting the legacies of persistent colonial processes. Contesting the assumptions that these histories have been fully explored, Gegeo examines Kwara'ae indigenous epistemology to ground and delineate constructions of place, space, and indigeneity. Within this specific context, he asks: What does it mean to be indigenous, and is indigeneity about place or space? Committed to dehegemonization, Gegeo points to the possibilities enabled by conceptual reconfigurations in the face of the cultural and political rupture that marks the conflict between Guales and Malaitans within the context of interisland migration and an increasing transnationalism. Noting the Kwara'ae definition of space as a location a person occupies and a definition of place as portable, Gegeo distinguishes nine different definitions of "place" from which to see and interact with the world and interpret one's social realities. These "places" include geographical and physical locations, genealogical standing within one's kin group, one's access to land, positionality with regard to one's ability to speak, one's native fluencies, the assumed connection between one's identity and knowledgeable authority, responsibility to place, sharing a common worldview constructed by Kwara'ae ontology and epistemology, and knowing one's own cultural model and interpretive framework.

He discusses what cultural rupture has meant and will mean to Malaitan concepts of indigeneity, place, and space-noting return-migration for Malaitans and the rupture of a Solomon Islands national identity as two key developments. Gegeo argues that the ethnic-political conflict has intensified a narrower Malaitan perspective on indigeneity-one now being redefined more exclusively. In sum, he suggests that these conditions will result in an implosion of "place" and an explosion of space. Noting the increase in the Malaitan diaspora, further transformation of concepts of place and indigeneity, Gegeo points to broader implications for transnationalism and ecological impact. For Gegeo, the "fragmentation" appears to be caused by globalization and neocolonialism. Yet drawing from his delineation of Kwara'ae concepts of place and space, one can 
detect an indigenous dimension of fragmentation, produced by the very strict definitions of local and regional indigeneities and their portabilities. Strict and portable indigenous identities can also play havoc with nationalist agendas, implicating them in a complex relationship with global and neocolonial forces - the postcolonial condition with deep, autonomous, native roots and culture, to raise the political and analytical and theoretical ante. Gegeo's paper wrestles with the consequences of such deep, strict, and transplanted roots without necessarily relinquishing the political and cultural promise of the nation.

WE WOULD вOTH LIKE TO THANK all of the contributors to this volume; all of the participants of the symposium; Lauren Gogarty of Barefeet Webdesign for mounting the website for Native Pacific Cultural Studies on the Edge; Jewel Castro for allowing us to use her beautiful art work for our promotional materials; James Clifford for his enthusiastic support and encouragement; Chris Connery and Gail Hershatter, codirectors of the Center for Cultural Studies at the University of California at Santa Cruz, for their generous institutional sponsorship; staff at the Center for their reliable assistance: Patricia Smith and Katy Elliot; the University of California Pacific Rim Research Program, which awarded a Pacific Rim Grant for the symposium; Editor Geoffrey White and Managing Editor Linley Chapman of The Contemporary Pacific; the manuscript reviewers for their critical and useful input; the editorial board of The Contemporary Pacific; and the University of Guam's National Resource Center for Micronesian Studies. Diaz would especially like to thank Christine Delisle, Maria "Mom" S N Taitano, Maria T Delisle, Dr Lawrence Cunningham, Mr Manny Sikau, and Dr Mary Spencer, Dean, College of Arts and Sciences, University of Guam. Kauanui extends special mahalo to Keta Miranda, Joanne Marie Barker, Glen Mimura, and Khyla Russell and Judith Bennett.

\section{Notes}

I We acknowledge that there is a whole range of classificatory politics of the terms Native, aboriginal, indigenous, First nation. Herein we use "Native" and "indigenous" interchangeably and recognize that these terms hold different currency and resonance in the United States, Canada, Australia, New Zealand, and beyond.

2 These definitions are relatively recent, and oscillate between being affectionate, derogatory, romanticized, and essentialized. Thus it is important to note deeper, older denotations and connotations. For example tatte carries an older 
meaning and connotation of something or someone who practices old traditions or who speaks an older dialect. In modern times, that oldness in practice and speech, found in southern Guam and in the Northern Marianas, especially Rota or Tinian, would also begin to carry the derogatory connotation of "backward" or primitive, or, in a glorified antimodern sense, "pure" or more "authentic" than the other Chamorros. The term po-asu, which translates as "smelling like smoke," or having a smoky coloration, in this century began to be applied to "half-castes" or mixed bloods, especially children of mixed Chamorro and apaka (white) parents. More recently, the term po-asu would be applied by Chamorros on island to diasporic Chamorros in the United States who now seem to prefer to act like Americans in speech or habit or sensibility.

3 These are internal self-distinctions usually invoked within specific communities that otherwise project a more stable, unified identity vis à vis nonmembers (what Hawaiians call haole or foreigner). As necessary components of self-identification (but not restricted to neo- and postcolonial conditions) they are also part of a cultural and historical repertoire of self-articulation that has an integrity that should be respected and not simply dismissed as mere constructions. They can be likened to intrafamily critiques in which family members can engage but nonfamily members had better not dare.

4 The routedness of roots is the central point of James Clifford's Routes: Travel and Translation in the Late Twentieth Century (Cambridge, MA and London: Harvard University Press, I997). Here Clifford builds on earlier work by Paul Gilroy in There Ain't No Black in the Union Jack: The Cultural Politics of Race and Nation (London: Hutchinson, 1987) and The Black Atlantic: Double Consciousness and Modernity (Cambridge, MA: Harvard University Press, 1993).

5 For relevant works on Pacific Christianities and religious movements, see Ben Burt Tradition and Christianity: The Colonial Transformation of a Solomon Islands Society (Chur, Switzerland and Langhorne, PA: Harwood Academic Publishers); Christine Dureau "Mixed Blessings: Christianity and History in Women's Lives on Simbo, Western Solomon Islands" (PhD dissertation, Anthropology, Australian National University, I994); Vicente M Diaz "Repositioning the Missionary: The Beatification of Blessed Diego Luis de Sanvitores and Chamorro Cultural and Political History" (PhD dissertation, History of Consciousness, University of California, Santa Cruz, I992); James Clifford Person and Myth: Maurice Leenhardt in the Melanesian World (Durham, NC, and London: Duke University Press, I992); Geoffrey White Identity through History: Living Stories in a Solomon Islands Society (Cambridge: Cambridge University Press, 1991); Margaret Jolly's essays, “'To Save the Girls for Brighter and Better Lives': Presbyterian Missions and Women in the South of Vanuatu, I884-I870" (Journal of Pacific History 26 (I): 27-48) and "Sacred Spaces: Churches, Men's Houses and Households in South Pentecost, Vanuatu," in Jolly and Martha Macintyre's edited volume, Family and Gender in the Pacific: Domestic Contradictions and 
the Colonial Impact (Cambridge: Cambridge University Press, 213-235, 1989); John Barker's edited volume Christianity in Oceania: Ethnographic Perspectives (Lanham, MD, New York, and London: University Press of America, I990); David Hanlon's essays "Gods vs Gods" and "Strategies of Salvation" in Upon a Stone Altar: A History of the Island of Pohnpei to I 890 (Honolulu: University of Hawai'i Press, I988, 87-II 2, and I I3-I43); Gary Trompf's edited volume, The Gospel Is Not Western: Black Theologies from the Southwest Pacific (New York: Orbis Press, 1987); and James A Boutilier, Daniel T Hughes, and Sharon Tiffany's edited collection, Mission, Church, and Sect in Oceania (Lanham, MD, New York, and London: University Press of America, 1978).

6 For works that address "American desires" in the Pacific see Rob Wilson Reimagining the American Pacific (Durham, NC, and London: Duke University Press, 2000); Robert C Kiste, "United States" in Tides of History: The Pacific Islands in the Twentieth Century, edited by K R Howe, Robert C Kiste, and Brij V Lal (Honolulu: University of Hawai'i Press, 1994); Arthur Power Dudden The American Pacific (New York: Oxford University Press, 1992, 227-257); and Ron Crocombe The Pacific Islands and the USA (Rarotonga: Institute of Pacific Studies, University of the South Pacific and Honolulu: Pacific Islands Development Program, East-West Center, 1995). See also American Anthropology in Micronesia: An Assessment, edited by Robert C Kiste and Mac Marshall (Honolulu: University of Hawai'i Press, 1999); and David Hanlon Remaking Micronesia: Discourses over Development in Pacific Territory, 1944-1982 (Honolulu: University of Hawai'i Press, I998).

7 While social sciences have traditionally defined the composition of Pacific studies, literature, film, video, and contemporary arts now join the field in formidable ways that have also engendered new discursive styles (see White and Tengan 38I-4I6). See also Cynthia Franklin, Ruth Hsu, and Suzanne Kosanke's recent special issue, Navigating Islands and Continents: Conversations and Contestations in and around the Pacific, of Literary Studies East and West (volume I7); Rob Wilson and Vilsoni Hereniko, editors, Inside Out: Literature, Cultural Politics, and Identity in the New Pacific (Lanham, MD: Rowman \& Littlefield, I999); Rob Wilson and Arif Dirlik, editors, Asia/Pacific as Space of Cultural Production (Durham, NC, and London: Duke University Press, 1995). The South Pacific Association for Commonwealth Literature and Language Studies also highlights Pacific Islander literary production. Another development here includes the Talanoa series at the University of Hawaici Press, which has enabled the reprinting of major Pacific Islander novels by authors such as Albert Wendt, Patricia Grace, Epeli Hau'ofa-making these works, previously published in Fiji and New Zealand, widely available to United States audiences. Yet another recent emergence is the literary journal Storyboard: A Journal of Pacific Imagery, published from the Department of English and Applied Linguistics, University of Guam. First published in I99I, Storyboard (see film and video, later) has begun 
to feature the work of new Micronesian writers north of the equator. For earlier assessments of Pacific Literature, see Subramani South Pacific Literature: From Myth to Fabulation (revised edition, Suva: Institute of Pacific Studies, University of the South Pacific, 1992) and Albert Wendt, editor, Nuanua: PacificWritings in English since I980 (Talanoa: Contemporary Pacific Literature, Honolulu: University of Hawai'i Press, 1995). Another exciting new work is the Terenesia compact disc, featuring the spoken work and poetry of Teresia Teaiwa and Sia Figiel (2000).

On film and video, see Merata Mita "The Soul and the Image" (36-53) and Barry Barclay "Amongst Landscapes" (I I6-I29) in Film in Aotearoa/New Zealand, edited by Jonathan Dennis and Jan Bieringa (Wellington: Victoria University Press, I992); Norman Douglas "Electric Shadows in the South Seas: The Pacific Islands in Films, A Survey" and "Comments," in Moving Images of the Pacific Islands: A Guide to Film and Videos, compiled by Diane Aoki (Honolulu: Center for Pacific Islands Studies, 1994 [now available electronically through the Moving Images website at the University of Hawaici at http://www.hawaii.edu/ oceanic/film/]); James Mellon "Images of Micronesia on Film and Video" in Pacific History: Papers from the 8th Pacific History Association Conference, edited by Don Rubinstein (Mangilão: University of Guam Press, I992, 385-403). Another useful publication is another "storyboard," Storyboard: A Quarterly Journal of the Pacific Islanders in Communication. The organization Pacific Islanders in Communication was established in the late I980s to promote Pacific Islander programming for US Public Television. Its efforts have also spawned a new level of attention as well as interest in networking among native producers and filmmakers, and native filmmakers and anthropologists. For the former, see for example Ruth Tuiteleleapaga "Sima Urale: Rising Star" (Storyboard I: November 1996), and for the latter, see Joseph Camacho "Wooden Boats" (Storyboard 4: Spring 1999, 2-4).

Along with scholarship that concentrates on Pacific cultural production, interdisciplinary feminist and gender studies are also a growing component of Pacific studies. Groundbreaking work in this area includes Ngahuia Te Awekotuku, Mana Wabine M ori: Collected Writings on M ori Women's Art, Culture, and Politics (Auckland: New Women's Press, 199r); Family and Gender in the Pacific: Domestic Contradictions and the Colonial Impact, edited by Margaret Jolly and Martha Macintyre (Cambridge: Cambridge University Press, 1989, 213-235); Anne Perez Hattori's doctoral dissertation, "Colonial Dis-ease: US Naval Health Policies and the Chamorros of Guam" (History Department, University of Hawai'i at M noa, I999).

Other developments include Te Pua: The Journal of Puawaitanga, which features $\mathrm{M}$ ori women's critical works (Auckland: International Research Institute for $\mathrm{M}$ ori and Indigenous Education, University of Auckland). See the special issue of Te Pua entitled Indigenous Women and Representation, guest edited by 
Leonie Pihama (2000). See also a special issue of Women's Studies International Forum entitled Migrating Feminisms: The Asia/ Pacific Region, coedited by Kalpana Ram and J K haulani Kauanui ( 1998); Sites of Desire, Economies of Pleasure: Sexualities in Asia and the Pacific, edited by Lenore Manderson and Margaret Jolly (Chicago and London: University of Chicago Press, 1997); Cecilia C T Perez "Signs of Being: A Chamoru Spiritual Being" (M A Plan B paper, Center for Pacific Islands Studies, University of Hawai'i, I997); Toi Wabine: The Worlds of $M$ ori Women, edited by Kathie Irwin and Irihapeti Ramsden (Auckland: Penguin Books, 1995); Sustainable Development or Malignant Growth? Perspectives of Pacific Island Women, edited by 'Atu Emberson-Bain (Suva: Marama Publications, 1994); Lisa Kahaleole Chang Hall and J K haulani Kauanui "Same-Sex Sexuality in Pacific Literature," in Asian American Sexualities, edited by Russell Leong (New York and London: Routledge, I994); two essays by Haunani-Kay Trask, "Women's Mana and Hawaiian Sovereignty," I I I-I 30, and "Pacific Island Women and White Feminism," 263-278 (From a Native Daughter, 1993); the collection addressing militarism and neocolonialism, Women's Voices on the Pacific: The International Pacific Policy Congress, edited by Lenora Foerstel (Washington, DC: Maisonneuve Press, I99I); Teresia Teaiwa "Microwomen: US Colonialism and Micronesian Women Activists," in Pacific History: Papers from the 8th Pacific History Association Conference, edited by Don Rubinstein (Mangilão: University of Guam Press, I992, I25-I42); Laura Torres Souder Daughters of the Island: Contemporary Chamorro Women Organizers on Guam (second edition, Lanham, MD and Mangilão: University Press of America and Micronesian Area Research Center, 1992); Haunani Kay Trask Fighting the Battle of Double Colonization: The View of a Hawaiian Feminist (Women in International Development Working Paper 52, Michigan State University, 1984). See also the forthcoming special issue of Pacific Studies that focuses on gender, sexuality, and identity, coedited by Caroline Sinavaiana-Gabbard and J K haulani Kauanui, Women Writing Oceania: Weaving the Sails of the Waka.

Many Pacific women are taking up issues of gender, feminism, and sexuality in their literary works. See the poetry works of Konai Helu Thaman, Teresia Teaiwa, Cecilia C T Perez, Anne Perez Hattori, Christine T Delisle, Jully Makini, Noumea Simi, Selina Tusitala Marsh, Grace Mera Molisa, Momoe von Reiche, Caroline Sinavaiana-Gabbard, Haunani-Kay Trask, and Sia Figiel, and the creative fiction by Patricia Grace, Leialoha Apo Perkins, Ngahuia Te Awekotuku, and Sia Figiel.

8 Well before the formation of Pacific studies proper at the University of Auckland, the important Polynesian Society had been founded in I 892, made up of a small group of scholars who worked to record the life and language of $\mathrm{M}$ ori and other Pacific peoples. Issued since I892, the Journal of the Polynesian Society is the longest-serving academic journal devoted to the scholarly study of Pacific 
peoples. See Journal of the Polynesian Society Centennial Index I892-I99I, compiled by Dorothy Brown (Auckland: The Polynesian Society, 1993). The Polynesian Society can be contacted at the Department of M ori Studies at the University of Auckland, New Zealand.

9 There is also the much older Pacific Science Congress, founded in the I920s, whose journal Pacific Science has largely featured work in the natural sciences, with less attention to the social sciences. And there is the Société des Océanistes, founded in Paris in 1946, which publishes the Journal de la Société des Océanistes.

Io There is no doubt that the association has succeeded in creating a community of scholars whose work marks a common regional commitment. But in general, scholars outside the United States are minimally involved. The association also continues to assess its inconsistent engagement with indigenous Pacific scholars, who are not well represented.

I I Although here we note the Pacific associations that have served as major players in Pacific studies, we recognize the strong regional organizations and gatherings that have been vital to Pacific studies scholarship and policy development. A strong example includes the Waigani seminars hosted by the University of Papua New Guinea that began in 1967 as yearly conferences (Geoffrey White, personal communication). Other robust and emerging networks include the Pacific Post-Secondary Education Council, which involves the tertiary institutions in Micronesia; the Pacific Regional Education Laboratory in Honolulu and its annual Pacific Educators Conference (which draws the largest numbers of Pacific Islander educators), and the emerging networks of Community Colleges across the Federated States of Micronesia.

I 2 Work in Flux brought together conversations among academics, artists, and students from the Pacific and Australia "about a postcolonial reading, writing, and teaching of the past." See Work in Flux, edited by Emma Greenwood, Klaus Neumann, and Andrew Sartori (Melbourne: Melbourne University History Department, I995).

I3 Many of these benefited from direct and indirect involvement, leadership, and financial support from the Center for Pacific Islands Studies at the University of Hawai'i at $\mathrm{M}$ noa, in particular. For a history of the center, see Agnes Quigg History of the Pacific Islands Studies Program at the University of Hawai $i$, 1950-1986 (Working Paper Series, Honolulu: Pacific Islands Studies Program, University of Hawai'i, 1987 ).

I4 The debate, or debacle, as we characterize it here, involved a particular way in which the critical injunction to historicize cultural critique was applied in the Pacific in specific response to the emergence of Native nationalism and activism. The first of two infamous cases involve exchanges between the late Roger Keesing (1989; 199I) and Haunani-Kay Trask (I99I) and Jocelyn Linnekin (I99I) in the pages of The Contemporary Pacific. For further reading, see Hau- 
nani-Kay Trask, "From a Native Daughter" (I47-I59) and "What Do You Mean 'We,' White Man?” ( I6I-I78) in From a Native Daughter (Monroe, MN: Common Courage Press, I993). Literature contributing to the $\mathrm{M}$ ori case includes Alan Hanson "The Making of the M ori” American Anthropologist 9I (I989): 890-902; H B Levine "Comment on Hanson's 'The Making of the M ori'" American Anthropologist 93 (I99I): 444-446; and A Ballara "Pakeha Uses of Takitimutanga: Who Owns Tribal Tradition?" Stout Center Review 3 (March I993): I7-2I. Other works on the politics of tradition include Lamont Lindstrom and Geoffrey White "Introduction: Custom Today" Anthropological Forum 6 (4, I993): 468-473; Margaret Jolly and Nicholas Thomas "The Politics of Tradition in the Pacific: Introduction" Oceania 62 (4, I992): 24I-248; and Margaret Jolly "Specters of Inauthenticity" The Contemporary Pacific 4 (I992): 49-72. Jocelyn Linnekin's articles on this topic include "On the Theory and Politics of Cultural Construction in the Pacific" Oceania 62 (4, I992): 249-263; "Cultural Invention and the Dilemma of Authenticity" American Anthropologist 93 (I99I): 446-449; and "The Politics of Culture in the Pacific" in Cultural Identity and Ethnicity in the Pacific, edited by J Linnekin and Lin Poyer (Honolulu: University of Hawai'i Press, I990, I-I6; see also the introduction to that volume). See also, Richard Handler and Jocelyn Linnekin "Tradition, Genuine or Spurious?" Journal of American Folklore 97 (I984): 273-290; and Linnekin's "Defining Tradition: Variations on the Hawaiian Identity," American Ethnologist Io (I983): 24I-252.

I5 Useful introductions can be found in Cultural Studies, edited by Lawrence Grossberg, Cary Nelson, and Paula Treichler (London: Routledge, I992); The Cultural Studies Reader, edited by Simon During (New York and London: Routledge, I993); Stuart Hall: Critical Dialogues in Cultural Studies, edited by David Morley and Kuan-Hsin Chen (London and New York: Routledge, I996); Introducing Cultural Studies, edited by Ziauddin Sardar and Borin Van Loon (New York: Totem Books, I998); There Ain't No Black in the Union Jack: The Cultural Politics of Race and Nation, by Paul Gilroy (London: Hutchinson, I987); Routes: Travel and Translation in the Late Twentieth Century, by James Clifford (Cambridge, MA, and London: Harvard University Press, I997); and What is Cultural Studies? by John Storye (London: Edward Arnold, I996).

I6 For prime cultural studies works on diaspora, see Cartographies of Diaspora: Contesting Identities, by Avtar Brah (London and New York: Routledge, I996); Questions of Travel: Postmodern Discourses of Displacement, by Caren Kaplan (Durham, NC: Duke University Press, I996); and the works of Paul Gilroy mentioned earlier.

I7 For recent ethnographic work on Pacific diaspora to northern California, see Voyages: From Tongan Villages to American Suburbs, by Cathy Small (Ithaca, NY and London: Cornell University Press, I997). 


\section{Bibliography}

Diaz, Vicente M

I996 Moving Islands: Toward an Indigenous Tectonics of Island Historiography. Paper presented at Contested Ground, Pacific Islands Studies Conference, University of Hawai'i at M noa, Honolulu, December.

forthcoming Sacred Tensions. The Micronesian Educator. Annual. College of Education, University of Guam.

Geertz, Clifford

I998 Deep Hanging Out. New York Review of Books, October. Hau'ofa, Epeli

I993 Our Sea of Islands. In A New Oceania: Rediscovering Our Sea of Islands, edited by Epeli Hau'ofa, Eric Waddell, and Vijay Naidu, 2-I 6. Suva: School of Social and Economic Development, University of the South Pacific in association with Beake House.

I997 The Ocean in Us. In Dreadlocks in Oceania I, edited by S Mishra and E Guy, I24-I48. Suva: Department of Literature and Language, University of the South Pacific.

2000 Pasts to Remember. In Remembrances of Pacific Pasts: An Invitation to Remake History, edited by Robert Borofsky, 453-47 I. Honolulu: University of Hawai'i Press.

Kabutaulaka, Tarcisius Tara

I993 The Bigness of Our Smallness. In A New Oceania: Rediscovering Our Sea of Islands, edited by Epeli Hau'ofa, Eric Waddell, and Vijay Naidu, 9I-93. Suva: School of Social and Economic Development, University of the South Pacific in association with Beake House.

Kauanui, J K haulani

I998 Off-Island Hawaiians "Making” Ourselves at "Home”: A (Gendered) Contradiction in Terms? Women's Studies International Forum 2 I (6): 68I-693. Special issue: Migrating Feminisms: The Asia/Pacific Region, edited by Kalpana Ram and J K haulani Kauanui.

Keesing, Roger

I989 Creating the Past: Custom and Identity in the Contemporary Pacific. The Contemporary Pacific I:I9-42.

I99I Reply to Trask. The Contemporary Pacific 3:I68-I7I.

Lewis, David

I970 We, the Navigators. Honolulu: University of Hawai'i Press.

Linnekin, Jocelyn

I99I Text Bites and the R-Word: The Politics of Representing Scholarship. The Contemporary Pacific 3:I72-I77.

Smith, Linda Tuhiwai

2000 Decolonizing Methodologies: Research and Indigenous Peoples. London and New York: Zed Press. 
Teaiwa, Teresia

I995 Preface. Searching for Nei Nim'anoa. Suva, Fiji: Mana Publications.

I997 Yaqona/Yagona: Roots and Routes of a Displaced Native, Dreadlocks in Oceania I, edited by S Mishra and E Guy 7-I3. Suva: Department of Literature and Language, University of the South Pacific.

Tobin, Jeffrey

I995 Cultural Construction and Native Nationalism: A Report from the Hawaiian Front. In Asia / Pacific as Space of Cultural Production, edited by Rob Wilson and Arif Dirlik, Durham, NC: Duke University Press.

Trask, Haunani-Kay

I99I Natives and Anthropologists: The Colonial Struggle. The Contemporary Pacific 3:I 59-I67.

I993 From a Native Daughter: Colonialism and Sovereignty in Hawai'i. Monroe, ME: Common Courage Press.

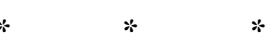

\title{
Appendix
}

\author{
Native Pacific Cultural Studies on the Edge \\ Oakes Learning Center, Oakes College \\ University of California, Santa Cruz \\ February I I \& I2, 2000
}

Friday, February i th

9:00 Welcome and Introduction: J K haulani Kauanui and Vicente M Diaz, Convenors

9:I5 Keynote speaker, Jim Clifford, "Indigenous Articulations"

I०:०० Q \& A

IO:I5 break

Iо:30 J K haulani Kauanui “Indigeneity, De-Racination and 'Off-Island' Hawaiians"

I I:०० Geoffrey White and Ty K wika Tengan "Disappearing Worlds: Anthropology and Cultural Studies in Hawai' $i$ and the Pacific"

I I:30 Discussants: Margaret Jolly and Jon Kamakawiwo'ole Osorio

I 2:00 Q \& A

I 2:I 5 lunch

I:30 Teresia Teaiwa "Lo(o)sing the Edge"

2:00 Jonathan Kamakawiwo'ole Osorio, "I Call You Angel of Death: Mo'olelo about Nationhood"

2:30 Discussants: Dana Takagi and Sa'iliemanu Lilomaiava-Doktor

3:00 Q \& A

3:I5 break 
3:30 Roundtable with Mike Perez, April Henderson, Joakim Peter 4:30 Q \& A

5:00 pau

5:30 Reception for Jewel Castro, Porter Faculty Gallery, art exhibit "Red House: Daughters of Salamasina”

Saturday, February I 2 th

9:00 Welcome

9:I5 Keynote speaker, David Welchman Gegeo "Cultural Rupture and Indigeneity: The Challenge of (Re)Envisioning 'Place' in the Pacific"

Io:०० Q \& A

IO:I5 break

I0:30 Margaret Jolly "On the Edge? Indigeneity and Diaspora in the Pacific"

I r:०० Vicente Diaz "Sailing into the Sunset (Boulevard): Tracking the Disturbing (ly) Familia(r) in Southern California"

I I:30 Discussants: Teresia Teaiwa, Chris Connery, Glen Mimura

I 2:00 Q \& A

I 2:30 lunch

I:45 Roundtable with Ty K wika Tengan, Adria Lyn Imada, John Chock Rosa 2:45 Q \& A

3:I5 Closing themes, future prospects

4:०0 pau 